\title{
Aliens, Humans, Animals, \& Luck: Animal Treatment \& Human Morality
}

\author{
Randall S. Firestone \\ Department of Philosophy, El Camino College, Torrance, CA, USA \\ Email: Randyfirestone@verizon.net
}

Received 22 May 2016; accepted 30 July 2016; published 4 August 2016

Copyright (C) 2016 by author and Scientific Research Publishing Inc.

This work is licensed under the Creative Commons Attribution International License (CC BY). http://creativecommons.org/licenses/by/4.0/

(c) (i) Open Access

\section{Abstract}

This paper proposes two thought experiments to demonstrate that our current treatment of animals is immoral. The first thought experiment involves aliens coming to earth and doing to us what we do to animals-eating us, confining us in farms and zoos, doing experiments on us, etc. Drawing on the latest scientific research on the abilities of animals, this thought experiment seeks to show that there are more relevant similarities between human beings and animals than most people realize, and that the differences between us and many other animals are not morally relevant. Moreover, this thought experiment attempts to appeal primarily to our sense of justice by tapping into our emotions for ourselves rather than to the usual approach which appeals to our emotions for animals. The second thought experiment is similar to the first, but more centrally emphasizes the idea of luck. It will, in part, take an approach recommended by Donald VanDeVeer to employ Rawl's veil of ignorance to mask not only our natural and social starting places, but also our species-whether we are human or of another species. However, one serious objection made to VanDeVeer's approach will be circumvented, namely, that it is difficult to imagine ourselves as an animal. Rather, we will imagine that evolution has made it so we are not the smartest and most powerful species on earth. This thought experiment invites us to ask ourselves that if there were only two species to consider and we were the less advanced of the two, would we still not expect to be treated with dignity and respect? Both analogies ultimately challenge us to ask the following question: What principles of justice would we choose to govern the interactions between species if we were not the most intelligent and powerful species on earth?

\section{Keywords}

Animal Rights, Animal Welfare, Animals, Alien Analogy, Veil of Ignorance, Species, Thought Experiment 


\section{Introduction: Two Thought Experiments}

This paper will use two thought experiments to help demonstrate that our current treatment of animals is immoral. The first thought experiment will involve aliens coming to earth and doing to us what we do to animalseating us, confining us in farms and zoos, doing experiments on us, etc. Drawing on the latest scientific research on the abilities of animals, this thought experiment seeks to show that there are more relevant similarities between human beings and animals than most people realize, and that the differences between us and many other animals are not morally relevant. Moreover, this thought experiment attempts to appeal primarily to our sense of justice by tapping into our emotions for ourselves rather than to the usual approach which appeals to our emotions for animals.

The second thought experiment is similar to the first, but more centrally emphasizes the idea of luck. It will, in part, take an approach recommended by Donald VanDeVeer to employ Rawl's veil of ignorance to mask not only our natural and social starting places, but also our species — whether we are human or of another species. However, I circumvent one serious objection made to VanDeVeer's approach, namely, that it is difficult to imagine ourselves as an animal. We need not take such a substantial leap and imagine that we are of a less intellectual and moral development than we are. Rather, we will imagine that evolution has made it so we are not the smartest and most powerful species on earth. This thought experiment invites us to ask ourselves that if there were only two species to consider and we were the less advanced of the two, would we still not expect to be treated with dignity and respect? Ultimately, the thought experiment should move us to consider that we are lucky to be "at the top of the pecking order" so as to dominate the other animals on earth.

In effect, both analogies are doing the same thing-having us imagine that we are having done to us what we are doing to animals_-and asking us to consider both intellectually and emotionally what it is like to suffer injustice and mistreatment at the hands of other beings. Both analogies ultimately challenge us to ask the following question: What principles of justice would we choose to govern the interactions between species if we were not the most intelligent and powerful species on earth?

\section{Is There a Relevant Difference?}

Although historically farm animals have had far from idyllic lives, in many ways their lives were fairly good. For one, the farmers protected them from natural predators. Of even greater importance, since the farmer came in daily close contact with his animals, which were relatively few compared to the numbers on today's huge farms, and since the owner's quality of life and even survival were somewhat dependent on his animals, the owner often both knew and developed a relationship with each animal, seeing their individual personalities, intelligence and emotional natures, and in many cases developing bonds of affection.

In this regard, things have radically changed in our modern world. Those raising and tending to the animals are no longer caring farmers who know each animal. Rather, they can more accurately be characterized as insensitive factory workers on a production line which is there to maximize profit-an enterprise known today as factory farming. There are two reasons for this. First, there has been a tremendous population explosion which demands that much more food be produced. Second, with the unprecedented affluence of so many people in the industrialized countries, the demand for meat has skyrocketed. The confluence of these two factors have caused the modern stockyard to house many thousands of animals-animals far too numerous for their owners to know. These animals have become numbers instead of companions, and have been confined in and herded into ever-shrinking cages and fences. Animals are now treated as any other commodity from which a profit can be made. They are no longer seen as living, breathing, caring, thinking, and feeling beings; rather, they are treated more like cell phones, televisions, and computers whose only value is in the benefit or enjoyment they can provide to us. Their resulting lives are miserable and it is we who are making it so.

Examples of our everyday, deplorable treatment of animals is well-documented, ${ }^{1}$ and include such a severe overcrowding of chickens in cages that they defecate on each other, attack each other, and even have their claws

\footnotetext{
${ }^{1}$ Many movies have captured animal abuse first hand, such as “To Love or Kill: Man v. Animal” (Thomas, 1996) and "Peaceable Kingdom” (Tribe of the Heart, Ltd., 2004). The severe overcrowding of animals into excessively small areas may also be due in part to two additional factors: First, with the building and expansion of cities and industrial projects coupled with our current farming practices which dissipate needed topsoil, productive farm and ranch land suitable for the humane raising of animals has continued to disappear. For example, American Farmland Trust's website states that "50 acres of farm and ranch land are lost every hour to sprawl and development”, and "1.7 billion tons of topsoil vanishes to erosion each year in the U.S.- enough to fill 1200 Empire State buildings.” Second, with the substantial increase of population, the finite resource of land suitable for cultivation has made the land more expensive-thus also lending itself to the crowding of animals into ever smaller areas.
} 
grow around and become attached to their cages; the maiming and deaths of millions of animals every year, including rabbits, dogs and cats, for the testing of non-necessities such as household cleaners and personal care products, including perfume, even though there are alternative ways of testing these products which do not involve animals; ${ }^{2}$ the removal of baby male cows (veal) from their mothers immediately after their birth, their confinement in windowless dark stalls where there is no room to move, and their meals limited to a liquid diet that is full of antibiotics and hormones; and to maintain peace between animals that are crammed together so closely that they are literally on top of each other, the cruelly painful removal of animal body parts without the use of anesthesia, such as the beaks and toes of chickens, the horns of cattle, and the tails of piglets. ${ }^{3}$

The case that philosophers have made for both animal rights and vegetarianism is often based in large part on a formal principle of justice: In order to justify treating entity A and entity B differently, there must be a relevant difference between the two. ${ }^{4}$ Using this principle, it has been pointed that the animals we so often eat, such as cows, chickens and pigs, are similar to human beings in morally relevant ways, and the differences between ourselves and those animals are not morally relevant in a way that would justify our current treatment of them. As Bonnie Steinbock has said, "The fact that a cat is not a 'rational being', that it is not capable of moral responsibility, that it cannot make free choices or shape its life-all of these differences from us have nothing to do with the justifiability of pulling its tail” (Steinbock, 1978: p. 250). Although this paper will challenge Steinbock's characterization of the attributes of animals, even if we accept her characterizations arguendo, we could still conclude that the differences between ourselves and non-human animals do not justify our severely confining them, inflicting terrible suffering on them, and then killing them to eat them.

When arguing for the better treatment of animals, philosophers have focused on a wide and varied array of similarities between animals and humans. For example, Jeremy Bentham (Bentham, 1789) the founder of Utilitarianism, and Peter Singer (Singer, 1975), one of Utilitarianism's most vocal living proponents, have argued that since most of the animals that we eat feel pain in virtually identical ways and degrees as humans do, this morally relevant similarity should preclude our inflicting pain and suffering upon them. While this position may seem a convincing indictment against our current factory farming practices, the utilitarian position may seem less compelling for the position that we should not eat these animals if they were treated humanely until their death. After all, if we do not cause them pain and suffering, does not the limited intellectual, emotional and moral development of animals constitute a relevant difference that would justify our obtaining nourishment and sustenance from them? ${ }^{5}$

Other philosophers have expanded beyond the Utilitarian analysis and have pointed out that animals are similar to us in many additional morally relevant ways than just the ability to feel pain and pleasure. ${ }^{6}$

However, what about the obvious differences between ourselves and animals? Singer argues that human beings each have different intellectual abilities, and yet we believe that all human beings deserve equal moral consideration. In a similar fashion, the fact that animals have lesser intellectual abilities and moral capacities com-

\footnotetext{
${ }^{2}$ The fact that most of the testing on animals for household cleaners is unnecessary is demonstrated by the fact that many companies have abandoned such practices and have found alternative testing methods. The PETA website explains the problem and solutions as follows: "Every year, millions of animals are poisoned and killed in barbaric and outdated tests that attempt to evaluate the hazards of consumer products and their ingredients. In an effort to measure toxic effects, rats, mice, guinea pigs, rabbits, and other animals are forced to swallow or inhale massive quantities of a test substance or have a chemical smeared in their eyes or on their skin. It is now evident that tests on animals often do not predict outcomes in humans, and many non-animal test methods are available and continue to be developed...Today, hundreds of cosmetics and household-product companies have rejected animal tests and are taking advantage of non-animal testing methods, including cell and tissue cultures, reconstructed skin grown from human cells, and computerized "structure-activity relationship" models that allow extrapolation of existing data to predict the activity of a chemical.” (PETA website, 2016)

${ }^{3}$ A nice exposition of animal abuse was done in a pamphlet titled "Why Vegan” by Vegan Outreach (2016).

${ }^{4}$ This is Singer's "Principle of Equality.” Mark Rowlands uses the catchy phrase "No moral difference without a relevant natural difference.” (Rowlands, 1998: p. 15)

${ }^{5}$ Singer partially concedes as such when he states as follows: "That there is some significance, as far as wrongness of killing is concerned, in whether the being killed can think about the future, seems to me defensible. How much significance there is in this is a more difficult question, to which I have no clear answer... On the other hand, death is a greater or lesser loss depending on factors like the extent to which the being was aware of his or her existence over time, and of course the quality of life the being was likely to have, had it continued to live.” (Singer, 2009b: p. 576)

${ }^{6}$ For example, Tom Regan has argued that, like ourselves, the animals we eat have inherent value beyond any value that they have to us because they are "experiencing subjects of life" (Regan, 1983) By this, Regan means that animals have emotions, memories, beliefs, desires, a sense of the future, a psychological existence over time, and self awareness, and further, they engage in intentional actions-again, in much the same way that humans do. James Rachels has also pointed out many morally relevant similarities that animals bear to us: Animals live in communities, they communicate with each other, they have ongoing social relationships, they suffer pain, they experience happiness, they become fearful and distressed, and they lead relatively complicated lives. (Rachels, 1977)
} 
pared to most humans should not be a basis for a dismissal of their interests. As Singer states, "If possessing a higher degree of intelligence does not entitle one human to use another for his own ends, how can it entitle humans to exploit nonhumans for the same purpose?” (Peter Singer, 1975) Singer maintains that to allow such treatment would be to engage in "speciesism"-a prejudice or bias in favor of those of one's own species and against the members of other species.

The potential weakness in Singer's argument is that the differences in intellectual and moral capacities among human beings would seem, at least to most people, to pale in comparison to the vastly greater differences between animals and ourselves. There is a big jump from comparing the intellectual abilities of two human beings, say Einstein and myself, and comparing the differences in intellectual abilities between Einstein or myself and a cow. ${ }^{7}$

In this vein, one line of attack on Singer's position has been to argue that the differences between humans and animals are enormous while the similarities are somewhat trivial. It has been claimed that we mistakenly attribute greater mental abilities to animals than they actually possess due to our practice of anthropomorphism. For example, J.S. Kennedy in his book The New Anthropomorphism argues that we cannot help but to attribute human mental experiences, such as feelings, pleasure, pain, motivations, consciousness and other thoughts, to animals because it is built into us to project our abilities onto others. He further argues that because we cannot know what animals think we should not assume that they have similar thoughts to our own. However, Kennedy does acknowledge that most scientists who work closely with animals would disagree with him. ${ }^{8}$

A more reasonable response to Singer would be that although there may be important similarities between ourselves and animals, there are also significant and relevant differences that are being glossed over, and these differences add up to more than just a difference in degree, they are a difference in kind that is morally relevant. The argument continues that it can be conceded that animals feel pleasure and pain, similar to us, that they have relationships with each other, and that some animals exhibit a rudimentary or basic ability to reason and even exhibit morality, but the depth of their relationships, rationality, emotions, and capacity to think and act morally are so rudimentary, undeveloped, and limited that any comparison between them and ourselves is folly indeed. ${ }^{9}$ Ruth Cigman sets forth this position as follows:

\{Humans have certain complexities of experience which are not attributable to animals. I have in mind, for example, the fear of death, or of contracting a fatal disease; the desire for respect or esteem from others; the desire to lead a fulfilling life (for one's life to have a "point" or "meaning"); the desire to achieve certain goals and resolve certain problems; and finally, corresponding fears and desires on behalf of others. These thoughts or experiences suggest a reason why persons deserve greater moral concern than animals. (Cigman, 1980: p. 465)

It is to this position that I will turn my primary attention, in part because I believe that recent animal research makes it abundantly clear that the abilities and complexities of animals are not being fully appreciated by people such as Cigman. For example, it appears that many animals do understand and fear death, desire respect from others, and deeply care about others. Frankly, they exhibit a surprising degree of both rationality and morality.

\footnotetext{
${ }^{7}$ One response to this argument which is employed by both Singer and Rachels is the Argument from Marginal Cases. This Argument attempts to show that you cannot coherently believe both that all humans have moral status, and that all non-humans lack moral status. Singer and Rachels point out that some animals are more intellectually aware and developed than some "marginal" human beings-marginal in the sense that they do not possess the normal attributes and abilities as other adults. This includes children, the significantly mentally disabled person, and the person in the advanced stages of senility who may not be able to recognize the face of even his or her spouse or children, among others. They argue that if it is wrong to kill these people, then it is also wrong to kill animals with similar capacities, talents and characteristics. Furthermore, the argument claims that these animals should be treated with the compassion and respect that we would accord these same human beings who possess lesser than normal human intellectual and other developmental abilities.

${ }^{8}$ Kennedy argues that just as there was an extraordinary jump in properties and abilities from plant life to animal life, there has been a similar jump from animal life to human life. Although the human genetic code has substantial similarities to those of the animals we eat, Kennedy believes that the changes in our genetic code have emergent properties that give us abilities that far outstrip anything animals could ever do (See Kennedy, 1992: Chapter 6). I believe that his conclusions fly in the face of an abundance of recent animal behavior and genetics research, much of which have been done in the 24 years since Kennedy's book was published, that have documented the many abilities of animals, and their physiological similarities to humans. While Kennedy points out the human tendency toward anthropomorphism, he seems to be guilty of another human tendency-anthropocentrism. Moreover, even if Kennedy were right about our vastly greater abilities over animals, it does not necessarily follow that we can mistreat them or even eat them. It is important not to confuse abilities and power with morality.

${ }^{9}$ Some people who would seem to support this position might include Tibor Machan, William Baxter, Carl Cohen, Bob Bermond, Bonnie Steinbock and Ruth Cigman.
} 
Moreover, to the extent that human beings have a higher self-awareness, a deeper appreciation of life, and greater hopes and dreams for the future than all or most other animals, human life might be more valuable, but that does not mean that humans have the right to inflict pain or death on those animals without a very good reason to do so.

To this end, I will propose two thought experiments, both of which will be an attempt to emotionally appeal to one's sense of justice and to tackle the issue of the similarities and differences between ourselves and animals. The first thought experiment will utilize the idea of aliens coming to earth, ${ }^{10}$ and will seek to demonstrate that (1) there are many relevant similarities between ourselves and the animals, and these similarities include the areas we so often associate with being human—intelligence, emotions, morality and language, and (2) the differences that we have portrayed as so great are both not as great as is often purported, and also are not morally relevant at all. As such, whatever the differences between animals and ourselves, in a very important sense these differences are not a difference in kind that would allow us to treat animals as we do, or to eat animals for a rather trivial interest of ours - the good taste and pleasure that we derive from eating them.

The second thought experiment will utilize the ideas Rawls sets forth in his leading work A Theory of Justice (1971). One of those ideas is that the principles of justice should be chosen from within or behind a veil of ignorance. Following VanDeVeer, I will argue that this veil should be applied to species, and I will then explore the idea that we are lucky to be at the top of the food chain. This thought experiment is a further demonstration that the differences between animals and us do not legitimate our current insensitive treatment of them.

In the end, the two thought experiments, by appealing to our sense of justice, will seek to reinforce what Singer himself sought to do, namely, to show that our superior intellectual and other abilities are not a proper justification for our current treatment of animals. It is the hope that these experiments will help us bridge the gap between what we find to be moral behavior with respect to human beings and what we find to be morally permissible to do to animals.

\section{The Aliens Have Landed}

Let us imagine that aliens from a far-away planet in another solar system have come to Earth. They have technology far beyond anything we have witnessed, and they have a far superior intelligence than we have. They claim to come from a world of peace- a world filled with love and concern for all of the sentient beings that populate their planet, especially those beings with intellectual levels equivalent to the cats, dogs, cows, chickens, and pigs on our planet.

Earth was not chosen at random, rather, it was chosen after the careful observation and study of our planet and all of its inhabitants, including the myriad plants and animals, and its top animal, human beings. Indeed, earth was chosen because it is populated by humans - with whom the aliens have a particular interest: they want to eat us, do medical experiments on us, and put us into zoos and circuses. Such actions will involve limiting our freedom of movement and actions. In fact, they want to move almost all of us onto factory farms where we will spend our whole lives until we are slaughtered. In other words, the aliens intend to treat us in much the same way that we treat many of the animals on earth.

It should also be noted that the aliens do not need to eat us in order to survive, nor even to maintain their health, though eating us gives them great pleasure because they find us to be quite tasty. Moreover, confining and eating many of us will provide an additional benefit—a benefit that we will soon learn about from the aliens.

Not surprisingly, human beings are appalled at this. How could highly sophisticated beings who profess to value peace and love for all conscious and certainly rational beings think to do such things to us? We appoint a representative to talk to the alien in charge, and to argue on our behalf.

\footnotetext{
${ }^{10}$ The use of the idea of aliens in ethical analysis is of course not new. For example, in David Hume's support of the Argument from Evil (used to foster doubt on the existence of God), Hume tries to demonstrate how much evil and misery there is in the world through the thought experiment of a "stranger" who drops into our world and sees its horrible conditions (David Hume, 1779). Nor is the use of the alien analogy new to the ethical analysis of the human treatment of animals. In Chapter 2 of his book, Rowlands has an excellent alien thought experiment and philosophical analysis which he calls “The Independence Day Scenario.” (Rowlands, 1998: pp. 12-30) William Davis has a similar alien analogy to the one I use, but his purpose does not involve animal welfare; rather, it is to show that prudence, sympathy, and conscience are the three possible grounds of moral appeal (Davis, 1976: pp. 178-185). Hugh LaFollette presents the same basic scenario as I do, but his brief examination is limited to just a few sentences (See LaFollette, 1989: p. 85). Bernard Williams attacks the alien analogy on what I believe are somewhat weak grounds, as evident from a reply that Singer makes to Williams' paper as well for reasons articulated later in the body of this paper (See Williams, 2009: pp. 91-96; Singer, 2009a: pp. 97-101).
} 
Human: It is not right for you to treat us this way. We are intelligent creatures, who have the ability to reason, to deeply feel and care, to feel pain, to experience anxiety and emotional suffering, and to think and act morally, similar to you aliens. We should be treated with the respect and dignity that all rational and moral beings should be accorded.

Alien: Mankind regularly acts both irrationally and immorally. Let's take a look at your actions. You pollute the air that you breathe and the water that you drink- two things that your very lives depend upon. You continue to do so even though you know the harmful effects that you are causing to yourselves- the epitome of irrational behavior. Moreover, you continue to pollute although there are reasonable clean energy alternatives that your government and business leaders regularly discredit, disparage, and even ignore-often to please the very people who are most polluting your planet-the rich and powerful.

Your population is multiplying out of control and at a rate that your planet cannot support. Every year millions of people, including children, starve to death; you are using up the Earth's natural non-renewable resources; and the agricultural land you need to feed your growing populations is both disappearing under the cement of your cities and being damaged by the overuse of toxic pesticides. Yet, your populations continue to increase, and millions continue to starve. This is certainly irrational and immoral behavior.

You regularly go to war against people who you do not know and who present little real threat to you. Some of you, such as your suicide bombers, blow themselves up in order to kill others-convinced they will be rewarded by God and sent to a Heaven-even for killing innocent women and children. These suicide bombers sacrifice their lives and kill so many others even though they cannot prove Heaven exists, or that there is a God, or that if there is a God that such a God would reward such killing.

You mistreat, discriminate against, and enslave other human beings merely because their skin is of a different color than your own, thereby clearly acting neither rationally or morally.

You develop nuclear, biological, and chemical weapons that have the potential to wipe out most if not all life on Earth, ${ }^{11}$ and manufacture so many of these weapons that if only a portion of them are used you will effectively destroy yourselves. In fact, we can confidently predict that this will happen unless someone steps in to stop you. Your insistence in developing ever greater weapons to be used against your fellow man is neither rational nor ethical.

Your great writer Feodor Dostoyevsky saw man for what he was and is, and his words should be pondered by you:

And now while we consider bloodshed an abomination, we nevertheless engage in this abomination and even more than ever before... \{Man's \} worst defect is his perpetual immorality ...In short, one may say anything about the history of the world... The only thing one cannot say is that it is rational (Dostoyevsky, 1864: pp. 42, 46).

Have I given you enough evidence of your lack of rationality and morality? I can give you many more examples.

Human: I agree that mankind has certainly taken a turn in the wrong direction in many ways. However, your examples look at mankind as a whole, and the direction that our leaders have taken us. Most people, however, are rational and moral. The masses should not be condemned for the abuses of the few, nor for the poor choices made by the rich and powerful who run our world.

Alien: Your leaders are often a reflection of the rest of you. Most people on your planet have shown neither greater rationality nor morality than your leaders. For example, so many people around the world smoke cigarettes although they know that they have thereby increased their risk for numerous diseases. People smoke although they know that smoking kills a very high percentage of people who smoke. They even smoke in the presence of their friends and children although they know that second hand smoke also kills. Such actions are both irrational and immoral.

\footnotetext{
${ }^{11}$ Experts disagree how many nuclear weapons it would take to end all human and other life on earth. Besides the people directly killed in a nuclear detonation, two of the biggest long term effects are cancer contracted from the radioactive fallout, and the devastating environmental effects from an anticipated nuclear winter caused by the nuclear clouds that would block out sunlight. The website nucleardarkness.org states the following: "A large nuclear war would utterly devastate the environment and cause most people to starve to death. Already stressed ecosystems would collapse. Deadly climate change, radioactive fallout and toxic pollution would cause a mass extinction event, eliminating humans and most complex forms of life on earth.” (Nuclear Darkness, 2016) The website of the International Campaign to Abolish Nuclear Weapons states, "A war fought using 1,000 nuclear weapons-around 5 per cent of the total global stockpile-would render the planet uninhabitable.” (International Campaign to Abolish Nuclear Weapons: p. 8)
} 
Individuals buy sports utility vehicles and other automobiles that get poor gas mileage although they know that the gasoline used to run motor vehicles is one of the biggest sources of air pollution. Despite the fact that they could buy a car that exceeds 40 miles per gallon, they are happy to purchase the vehicle that gets only 20 or 25 miles per gallon and fouls your air.

Your so-called more advanced and educated societies are examples of greed and selfishness instead of benevolence and charity. Billions of dollars are spent on things people do not need, ${ }^{12}$ while others go hungry and homeless in their own communities. This is not an example of morality.

Moreover, so many of you would rather work long hours to pay for things that you do not truly need, and thereby spend less time with your children. Your greed is at the expense of your relationships and your family. This is not rational behavior. Should I go on?

Human: You have given some good examples that show that humans are often neither rational nor moral, but you cannot dispute that there are many instances where we do display rationality and morality. We often help others in need, and many people give of their time and money to charitable causes.

Alien: Although many of you do help others, and some of you are concerned about the animals on your planet, your human history is rife with torture and death in ways that most animals would not think of perpetrating. Even most dogs do not continue to attack another dog when the defeated one bares its throat in a sign of submission. Such mercy has so often been absent in human behavior. It is not just a lack of mercy that is our concern. You humans are often cruel to each other, and in war you demonize the other side so as to justify egregious conduct that results in the injuries and deaths of many innocent people. This is not a rare occurrence, or an exception to the rule. In the $20^{\text {th }}$ century alone, wars and political repression resulted in the deaths of over 150 million people. Clearly the goodness of some of you is countered by the badness of many of you.

Furthermore, with respect to your animals, your kindness to them pales in comparison to your cruel treatment of them. Although you have a greater capacity for moral conduct than do animals, you have exhibited immorality on a scale that dwarfs anything done by them.

Human: Even if humans are guilty of significant moral transgressions, we surely are often moral, and what's more, as you acknowledge, we have a great capacity to be moral. I think you are giving too much credit to animals. Except for the chimpanzees and apes, animals cannot reason, do not display deep emotions for and relationships with others, and do not exhibit moral behavior. Moreover, animals do not suffer misfortune in death because they neither have desires for the future nor an understanding of the finality of death. As such, we are much more similar to you than we are to the animals on our planet.

Alien: We have discussed how you have overestimated human rationality and morality in order to make it appear that there is a bigger difference between humans and animals than there actually is. You have also vastly underestimated the intellectual and moral development of the animals on Earth, and have ignored the findings of many of your scientists who closely observe and study these animals. ${ }^{13}$

\footnotetext{
${ }^{12}$ Unnecessary purchases have become so commonplace that we hardly notice their non-necessity. I have in mind such purchases as large energy-consuming homes, second homes that we barely use, sports cars, expensive cell phones, private jets, meals at the latest pricy restaurants, sending our children to private schools even if the public schools in the area are just as good or better, the myriad of technological expenses that include expensive computers, laptops, big-screen televisions, etc. Both the rich and the moderately well-off purchase these items while many others go homeless and hungry.

${ }^{13}$ In the pages that follow, I have the alien use documented animal behavior to demonstrate the abilities of animals. Many of the examples have been taken from the following books: Good Natured by Frans de Waal (De Waal, 1996); When Elephants Weep: The Emotional Lives of Animals by Jeffrey Moussaieff Masson \& Susan McCarthy (Moussaieff Masson, 1995); The Animal Ethics Reader, $1^{\text {st }}$ and $2^{\text {nd }}$ edition by Susan Armstrong \& Richard Botzler (Armstrong, 2003 \& 2008). Some of the descriptions of animal behavior and abilities were taken from articles over the past several years covering scientific studies that were reported in the press or in the journal Scientific American. For example, a May 2014 article indicates that wild orangutans have the capacity to perceive the future, prepare for it, and communicate those future plans to other orangutans; capuchin monkeys have a sense of fairness; scrub jays can relocate food that has been hidden for months; and rhesus monkeys will not pull a chain that will provide them with food if they believe it will harm another monkey (Bedard, 2014). A June 2015 Scientific American article written by two biologists had this to say: "Along with the observations of field researchers, these studies forced the recognition that animals were much smarter than we gave them credit for: chimps and crows make and use tools,; parrots solve problems using logic; elephants disable electric fences by dropping large rocks on them... What was needed for a fuller understanding of the social life of animals was the recognition that many animals, just like we humans, are embedded in complex social networks-the relationships that connect each individual to every other group member...Ethologists now know that many animals are much smarter, more behaviorally flexible and better able to learn than the pioneers of the field could have dreamed.” (Hasenjager \& Dugatkin, 2015: pp. 52, 55) Recently it was discovered that the octopus is a "surprisingly social" and "remarkably intelligent" animal which can quickly recognize individual humans, solve relatively complex puzzles, and open and close jars (Montgomery, 2015). For a relatively recent article which surveys the most current research on the physiological and cognitive capacities of animals, including sentience, self-awareness, memory, and mind-reading (attributing mental states to others), and considering mammals (including dolphins), amphibians, reptiles, fish, invertebrates, insects, spiders, mollusks, etc., see “Science, sentience, and animal welfare” by Robert C. Jones (Jones, 2013).
} 
Animals exhibit deep emotional attachments and affection for each other, and help each other when it is not in their self-interest to do so-an indication of moral behavior. For example, dolphins and whales act to save others of their species, often at great risk to themselves. Monkeys, significantly below chimpanzees on the evolutionary scale, take care of others of their kind that are born with serious disabilities, such as without sight or with the absence of arms and legs. These actions do not contribute to the caring monkey's survival, and in fact put them in jeopardy, and yet this extra work is taken on out of concern for the less fortunate and less able. Elephants express joy when being united with old friends. Birds give warning calls to allow others to escape a predator, although such action attracts the attention of the predator and puts the caller in danger. Many animals live in communities, and similar to humans, act to maintain peace among community members.

Additionally, animals have even been known to care for the sick, injured, or imperiled of another species. For example, porpoises have helped save humans at peril to themselves, and an elephant saved a rhino calf stuck in the mud-even when the calf's mother charged at the elephant. Moreover, some animals adopt the orphaned young of other species. This again seems to be a display of moral behavior.

Furthermore, animals do have desires for the future. Just as your biology causes you to want to survive into the future, so do animals. Animals desire to experience future physical and emotional pleasures, including the desire to see the future survival and well-being of their children and friends.

What's more, animals understand the finality of death better than many humans do. It is only humans that so badly wish to exist forever that they have created the notion of future existences for which they have little or no proof, such as the Christian idea of a future existence in Heaven or Hell, or the Eastern concept of reincarnation or multiple lives in succession. Animals do not do this. They rely on their observations and experience. They see their friends and loved ones die, and observe the bodies decompose over time. They understand when another animal will no longer be able to rise up again to provide either companionship or a threat. Animals such as elephants, horses, dolphins, dogs and monkeys have been observed to grieve at the death of a relative or companion in much the same way as humans do. More than humans, animals live with the threat of death, and understand its finality all so well.

You choose to ignore that the genetic codes of chimpanzees and apes differ by less than 5\% from your own, yet you still do harmful medical experiments on them against their will, and destroy their habitats so that many are fighting for their very survival. Chimpanzees have communicated with human beings using sign language, and have demonstrated a mastery of a vocabulary larger than small children. They also offer comfort to other chimpanzees after a fight has been lost, an action that seems to be motivated by affection and kindness, and not self-interest, and seems to display moral behavior.

You are also inconsistent in your reasoning about animals. For instance, you use them in your medical experiments with the assumption that they are very similar to yourselves, and their bodily and other reactions will mimic how humans will react under similar circumstances. For example, mice are used in many experiments because of their similarity to humans-as more than 80 percent of the mouse genetic code matches the human genetic code. Thus, you tacitly admit that the animals are quite like you, and yet you justify using them against their will and subjecting them to terrible pain and death by claiming that they are so different from you.

You have always greatly exaggerated your importance, value and uniqueness. Not so very long ago your scientists told you that earth was the center of the universe, and that your sun and all the suns of all the galaxies revolved around your planet. You believe that on your planet you and you alone were made in the image of God, and yet your best scientific evidence shows that you are just the top of a long evolutionary process. You have a saying that "power corrupts, and absolute power corrupts absolutely." You have used your power over the animals-largely ignoring their welfare, their needs, their interests, and their suffering.

If you would only look, you would see that animals form deep and loving relationships and emotional bonds between each other, use their reasoning ability to survive and enhance their lives, and assist and care for each other when it is of no obvious benefit to them. Our analysis of your planet indicates that humans can best be characterized as selfish, power-hungry, and prone to excess, and that the animals on your planet, while not as intellectually developed as you, are also not as morally destitute as so many people are.

Human: There is one very important difference between animals and humans that we have failed to consider -language. Like you, we are able to communicate needs, intentions, ideas and thoughts in sophisticated language. Our language has both words that have meanings, semantics, and rules for putting those words together, syntax. No other animal has both of these. It is our language that has allowed us to pass skills, knowledge, and wisdom to our children and future generations; to learn and to teach morality; to coordinate our efforts to 
achieve amazing things, such as wiping out diseases and going to the moon; to create grand works of art and architecture; and to build great civilizations. Our ability to communicate in sophisticated languages demonstrates our superiority over animals, and is one of the reasons that our intellectual and moral capacities have so outgrown those of the other creatures on earth. And in this ability we are very similar to you, which is why you should treat us well, although we have no such obligation when it comes to animals.

Alien: Again you have downplayed the differences between you and us, and have overstated the differences between you and the animals on your planet. We are able to communicate in ways you cannot even imagine. In fact, we can communicate with the animals on your planet. In communicative abilities, there is at least as big of a difference between you and us as there is between you and the animals on your planet.

Moreover, animals communicate far better than you realize. All animals, and even insects, communicate with each other through a great variety of methods. ${ }^{14}$ Most of the animals have essentially the same five basic senses that you do, that of sight, feel, hearing, smell and taste. It is through these senses and other body parts that communication takes place. For instance, sound waves are used to communicate in a myriad of ways: by whales and dolphins in the seas, and by elephants through sending and receiving vibrations in the ground. In fact, some of the animals have developed their senses, such as smell or sight, far in excess of your own. For example, your scientists have discovered that many animals, such as elephants, whales, giraffes, hippopotamuses, bats, and dolphins communicate in frequencies that are either lower or higher than the human ear can detect. And birds see colors in the ultraviolet spectrum that humans cannot see. Does that make them superior to humans or just different? Each species has developed the attributes and communication skills that it needs in order to best support its survival and the survival of its species, and this worked pretty well until recently when humans have multiplied to such an extent that the natural habitats of thousands of plants and animal species have been and are being rapidly destroyed.

You should keep in mind that even most human communication takes place on the non-verbal or non-language level, such as through vocal pitch, facial expressions, posture, gesture, and body language. Animals use these methods too. Both the animal kingdom and humans communicate through ritualized dances, songs, and chemical signals. For example, honeybees symbolically communicate through a dance which tells other bees how far away and in which direction there is food.

And what kinds of things are being communicated? The same types of things that humans discuss. Animal communications concern the defense of resources and territory, pleasure, sexual selection and relations, food and shelter, the identity of the leader of the group, the need for recognition and status, and emotions. Moreover, many animals use their communicative skills to teach their young how to act.

While it is true that none of the other animals have a full-blown semantics and syntax in their communicative repertoire that is as complex as your own, they have more language skills than you think. Many animals make different sounds to distinguish different objects and to convey different emotions. For example, your scientists, using recording devices and computers, have concluded what we already knew, namely, that prairie dogs have different words for different objects, including for their predators such as coyotes and hawks, and also for such non-threatening animals as elk, deer, antelope and cows. They also have different words that distinguish between a tall human in a yellow shirt and a short human in a green shirt. ${ }^{15}$ Clearly, they have a semantics that is relevant to their survival. Similarly, your scientists in Brazil have now recorded turtles talking. ${ }^{16}$ An African grey parrot has demonstrated that he understood English by correctly naming fifty objects, seven colors, and five

\footnotetext{
${ }^{14}$ Two good books that discuss the abilities of animals to communicate are Animal Talk by Tim Friend (Friend, 2004) and Chasing Doctor Doolittle: Learning the Language of Animals by Con Slobodchikoff (Slobodchikoff, 2012). In addition to speaking their own languages, animals also exhibit some understanding of human language. Peter Singer gives us several examples of animal research which reveals that the gorilla Koko scored between 70 and 95 on human IQ tests and understands about a thousand signs; that the great apes can use human sign language and demonstrate a kind of structured syntax; that dogs such as border collies can comprehend 200-300 human words, and that an African grey parrot named Alex grasped about 100 words and could answer novel questions (Singer, 2009b: pp. 568-569).

${ }^{15}$ Con Slobodchikoff has done extensive research into animal language in general, and prairie dog communication in particular (See Slobodchikoff, 2009 \& 2012).

${ }^{16}$ Victoria Gill reported for the BBC News as follows: "Scientists in Brazil have managed to eavesdrop on underwater "Turtle talk." "Their recordings have revealed that, in the nesting season, river turtles appear to exchange information vocally—communicating with each other using at least six different sounds. This included chatter recorded between females and hatchlings...They used microphones and underwater hydrophones to record more than 250 individual sounds from the animals...The noises the animals made were subtly different depending on their behavior. For example, there was a specific sound when adults were migrating through the river, and another when they gathered in front of nesting beaches. There was a different sound again made by adults when they were waiting on the beaches for the arrival of their hatchlings.” (Gill, 2014)
} 
shapes, and he spoke in English sentences that were appropriate for the context. Similarly, vervet monkeys have different alarm calls for different predators, with calls that distinguish between leopards, eagles, and pythons.

Even your use of syntax is not beyond the abilities of all of the animals. Both dolphins and some of the great apes have demonstrated the ability to learn artificial languages. For instance, Kanzi, a Bonobo, could understand 650 different sentences by the age of eight.

Vocal learning, which is the ability of an animal to modify its vocalizations based on its experience with other animals, has been found by your scientists to exist in whales, dolphins, harbor seals, and greater horseshoe bats.

Indeed, in the future your scientists will come to realize that animals communicate much more than you have previously imagined. There is neither as wide of a language gap nor of a thinking gap between yourself and the animals as so many humans have believed there to be.

Human: Even if it is true that animals can communicate better and are more intellectually developed than most humans realize, it is also the case that it is natural for humans to eat animals. It provides needed nutrition and contributes to our good health. Our planet functions so that those at the higher levels of the food chain eat those life forms that are lower on the food chain. This fosters our survival and well-being, and is part of the evolutionary process on our planet. As you can observe, many animals eat other animals, and yet in the case of these animals there would be no thought that they are in any way engaging in immoral behavior. The lion kills the deer, the wolf eats the lamb, and the big fish gobbles up the little fish. While it is natural and nutritional for humans to eat animals, it is not natural for you to eat us. You are from another world without human beings, so it cannot be said that it would be natural for you to eat us as it is natural for us to eat the animals on our own planet.

Alien: You are basically arguing that the fact that your planet has evolved by way of survival of the fittest somehow justifies your callous behavior toward animals. But just because humans have used their power to kill and eat animals does not make it the ethical thing to do. If so, then you should have no problem in letting us eat you as we are the strongest or fittest in this portion of the Universe.

Additionally, it is ironic for you to argue for what is natural when you so significantly alter nature, including raising animals in unnatural environments which suppress their instincts and removes them from the evolutionary pressures of natural selection which would hone their skills and abilities.

Moreover, think about this: The first humans lived in Africa, and it was a very long time before humans left the African continent. Should we then say that it is not natural for you to eat the animals of another continent such as North America? Of course not. In much the same way we can say that although we were born in a different place than earth, we have expanded to live in other areas and on different planets, and it turns out that humans are nutritious for us in much the same way as the buffalo of North America was and is for you. In a sense, since we are all in the same Universe and you provide nutrition for us, it is as natural for us to eat you as it is for you to eat many of the animals that you do.

Furthermore, it is actually debatable that eating animals is either natural or healthy for humans. Your own studies indicate that vegetarians have a lower risk of heart disease, stroke, many cancers, osteoporosis, diabetes, obesity, kidney stones, gallstones, and hypertension. The evidence is strong that a vegetarian diet is actually healthier for you than a meat-centered one. The fact that humans do not need meat in order to survive is amply demonstrated by the millions of vegetarians on your planet—with their superior health and increased life expectancy. $^{17}$

Regarding what is natural, your bodies more closely resemble herbivores than carnivores. ${ }^{18}$ For example, your intestinal tract is the same size as plant-eaters; your stomach acid that aids in digestion is 20 times less strong than the acid found in meat-eaters and again matches that found in herbivores; you have no claws to tear meat; and you have no sharp front teeth for tearing meat, rather, you have the rear flat molars found in plant-eaters that aid in the grinding and chewing of vegetables. It is no wonder that early man was primarily a vegetarian, and this should be of no big surprise since your closest neighbors on the evolutionary scale, chimpanzees, gorillas and other apes, are also primarily vegetarians.

Nonetheless, you do eat meat and in some sense we can say that it is natural for modern man to do so. However, since you can obtain all of your required nutrients from non-animal sources, then even if it is natural to eat

\footnotetext{
${ }^{17} \mathrm{~A}$ very good book on diet and nutrition that lists and explains the research in this area and the superiority of a vegetarian diet is The China Study, by T. Colin Campbell, Ph.D. and Thomas Campbell II, M.D. (Campbell, 2006). The scientific research shows that the more meat that is consumed, the higher the rates of heart disease and of numerous cancers, and the lower the life expectancy.

${ }^{18}$ See International Society of Krishna Consciousness, 1983: pp. 1-3.
} 
meat it is not thereby moral to cause the suffering and death of the animals. In other words, it is no justification to say that it is natural because you have always done this, and thereby it is moral for you to so act. Cannibalism has also been practiced by humans, and did provide nutrition, and so could be viewed as natural. But even if it were natural, cannibalism is not moral. Likewise, violence and oppression may be viewed as natural, but that does not make such actions moral. You have the ability to choose love, benevolence, and vegetarianism over hatred, oppression and the killing and eating of animals.

Although we would not call the lion or the wolf immoral because they killed and ate other animals, human beings are in a significantly different position. First, carnivores such as wolves and lions are made to eat meat, and seem to need to eat meat to survive. Humans do not. Second, even if these animals do not need to eat meat, they do not have the ability to see that eating only fruits and vegetables is the moral thing to do. Humans have that ability. What is sad is that the overwhelming majority of you ignore this moral ability and the great suffering and death that you visit upon the other conscious inhabitants of your planet.

Human: But why us? Can't you find another source for your food and medical experiments? If you can, and if you are so superior to us from a moral perspective, how can you kill and eat us, perform painful medical experiments on us, and otherwise use us for your own purposes? Since you are more rational and moral than we are, would it not be the ethical action to guide us, teach us, and respect us? I appeal to your concern for others, and your ability to love, appreciate, and value those less powerful than you. If you eat us, do experiments on us, and confine us, you would be engaging in planetism: you are treating us differently than you treat the beings on your own planet. Just because we come from another planet is no reason to mistreat us, or to fail to treat us as beings deserving of respect.

Alien: You accuse us of doing what you do. You engage in speciesism when you mistreat animals just because they are not one of your own species. How is that different then planetism? Moreover, we have chosen to eat you humans for a very specific reason-by confining and eating humans, we will significantly limit your numbers and power in a way that will aid the rest of the planet. Your plants and animals will once again be able to flourish. The animals over which you claim such superiority have not brought life on your planet to the edge of destruction, and have not wiped out tens of thousands of species of plants and animals as you have. You need to be stopped. The irony is that we care more about the other beings on your planet than you do, and our use, control, confinement, and regulation of human beings, including limiting your numbers, will be of benefit to the myriad of other earthly creatures who want to live and enjoy life.

What is our defender of humanity to say? He could take the position that prevails among most people, namely, that what humans have done and are doing to animals is morally acceptable. However, it seems that to be consistent he would have to concede that the aliens have the moral right to do the same to us. I doubt very many people would take this position if the aliens were coming for them, or came for their parents, spouses, and children.

The alternative is to admit that our treatment of animals has been immoral. If the aliens' superior intelligence, rationality, language ability, and morality are not relevant differences that would justify the aliens eating us and using us for their own purposes, then it seems that these same types of differences between ourselves and the animals are also not relevant differences that would allow for our current treatment of animals. And the aliens can even make a moral claim that we cannot make in regard to our treatment of animals - their actions toward us (in limiting our numbers and freedom) will save and help flourish millions of other innocent living, feeling and thinking beings - the animals we so callously mistreat.

Bernard Williams tried to discount the alien analogy by arguing that if it is moral to allow for cultural diversity and the cultural favoritism that often flows therefrom, which he thought most of us would not only approve but also encourage, then species favoritism is also acceptable. ${ }^{19}$

Williams failed to make the distinction between a favoritism which helps others as opposed to a favoritism which allows, encourages, or mandates harming others. While it is undoubtedly true that cultural diversity is a good thing which makes life more interesting and presents us with a myriad of perspectives to consider, it does not follow that in the name of fostering cultural diversity alone (and even cultural favoritism) we could morally

\footnotetext{
${ }^{19}$ Williams asks us to consider the following scenario: The aliens...have had much more successful experience than we have in running peaceable societies, .... and that too much species-self-assertion, or indeed cultural autonomy prove destabilizing and destructive. So, painlessly they will rid us, certainly of our prejudices, and to the required extent, of some of our cultural and other peculiarities...The situation that this fantasy presents is in some ways familiar. It is like that of a human group defending its cultural, possibly ethnic, identity against some other human group which claims to dominate or assimilate them (Williams, 2009: pp. 92-93).
} 
justify the mistreatment of one culture by another. Just as we can encourage cultural differences and even cultural favoritism without thereby condoning the harming of other cultures, we can encourage and celebrate human differences from animals, and favor our fellow humans by giving them additional assistance and love beyond what we provide animals, without harming animals. Acknowledging and appreciating differences is a far cry from supporting the mistreatment of those who are different than we are.

We should keep in mind that many of the harmful things we do to animals are unnecessary. We do not need to eat animals in order to survive or have fulfilling lives. We have a choice. Additionally, most of the animals that we eat, such as cows, chickens, and pigs, have significant similarities to us that should give us pause before inflicting injury or death upon them.

We should also notice that the aliens presumably would not have herded us into cages where we were literally on top of each other, nor withheld solid food from us until we were later killed and eaten (as we do with male calves to later serve as veal), nor shot us full of hormones and antibiotics, nor cut off our body parts in order to maintain order, nor performed surgeries on us without anesthesia, nor taken our babies from us shortly after birth-all actions routinely perpetrated in our factory farms. If what the aliens wish to do to us is not right, how much more wrong is it what we do to animals?

\section{The Luck of the Human}

John Rawls designed a thought experiment in his seminal book A Theory of Justice where we are to imagine people coming together to form a society. He calls this the original position. Rawls' technique for determining the just rules of a society is that people would select the rules behind a veil of ignorance where they would not know who they were. Specifically the veil would hide their social or natural starting places. For example, they would imagine that they did not know whether they were strong, intelligent, healthy, white, male, and/or rich or, on the contrary, weak, mentally deficient, physically disabled, black, female, and/or poor. This would ensure that one was impartial in choosing the rules and laws of society so that one did not favor themselves. Rawls thought this technique would result in our helping those people who were in the most disadvantaged positions because we, or our loved ones, could be in such a position.

Rawls, however, did not believe that his social contract approach would be of benefit to animals. Since it is only people (and not animals) who are coming together to form a society, Rawls believed it is only people who we need to consider when coming up with fair rules. Moreover, Rawls had no reason to suspect that in using this procedure, people would necessarily come up with rules, principles or laws that would be of significant protection to animals. Nor did he seem to allow us to use the veil of ignorance to mask that we are human beings as opposed to non-human animals. In spite of this, Rawls did make it clear that he believed humans owe moral duties to animals, but he asserted that one would have to look beyond his theory to establish those duties. ${ }^{20}$

Several philosophers have criticized Rawls in this regard, and have concluded that his moral philosophy can in fact be used to mandate the better treatment of animals. ${ }^{21}$ Donald VanDeVeer, for example, advocates that Rawls' veil of ignorance be extended to include all sentient creatures. He states, "If, then, the original position were fully neutral, its participants would not only have to be ignorant of the race, sex, or social position..., it would seem that they would have to be ignorant of their species membership as well...” (VanDeVeer, 1979: pp. 372-373)

VanDeVeer explains that without applying the veil of ignorance to mask which species one is in, the original

\footnotetext{
${ }^{20}$ Rawls states as follows: Last of all, we should recall here the limits of a theory of justice. Not only are the many aspects of morality left aside, but no account is given of the right conduct in regard to animals and the rest of nature...But it does not follow that there are no requirements at all in regard to them, nor in our relations with the natural order. Certainly it is wrong to be cruel to animals and the destruction of a whole species can be a great evil. The capacity for feelings of pleasure and pain and for the forms of life of which animals are capable clearly imposes some duties of compassion and humanity in their case (Rawls, 1971, 1999: p. 448). Ruth Abbey summarizes Rawls' position as follows: "By locating questions of humans' treatment of animals beyond the sphere of justice but within the requirements of morality Rawls challenges us to develop other ethical vocabularies for discussing relationships with non-humans.” (Abbey, 2007: p. 9)

${ }^{21}$ For an excellent argument using Rawls' concepts to support animal rights, see chapter 6 of Rowland's book (Rowlands, 1998: pp. 120-158). Pritchard and Robison suggest that participants in the original position should not be exclusively self-interested; rather, they may be compassionate toward both people and animals (Pritchard \& Robison, 1981: pp. 55-61), Ruth Abbey does a good job summarizing some of the criticisms of Rawls' exclusion of animals from the realm of justice as fairness, and for Rawls' failure to use the veil of ignorance to hide whether we are humans or animals when choosing the rules of justice for society (Abbey, 2007). See also Matthew Talbert who argues that social contract theory as enunciated by T. M. Scanlon (not Rawls) in his book What We Owe to Each Other can be extended to consider animal welfare under a "trustee model" where a principle for action is judged wrong if a nonhuman animal would offer (if it could do so) a reasonable objection based on its own interests (Talbert, 2006).
} 
position would be set up to yield social principles which would likely include unfair speciesist principles which favor one's own species at the expense of other species. ${ }^{22}$

There is a potential problem with trying to mask one's species: It seems more difficult to imagine that one could be a cow, pig, or chicken than that one could have been born with different color skin, or a severe physical or mental disability, or of the other sex. This point had been raised earlier by Bonnie Steinbock:

In addition, when we consider the severely retarded, we think, "That could be me.” It makes sense to think that one might have been born retarded, but not to think that one might have been born a monkey. And so, although one can imagine oneself in the monkey's place, one feels a closer identification with the severely retarded human being (Steinbock, 1978: p. 255).

Steinbock is undoubtedly correct that we can more easily imagine ourselves being born a severely retarded human than an animal, but that does not mean that we should not try to imagine it, nor that it would not benefit our moral development to so imagine it. The white racist may well have difficulty imagining being born a black person, but that does not mean he should not try to imagine it in order to increase his moral sensibilities. Additionally, with the recent scientific breakthroughs in the 38 years that have elapsed since Steinbock wrote her article, we now better understand the substantial genetic similarities between ourselves and the animals we eat and who are the subjects of our medical experiments. These animals are genetically much more similar to us than we could have previously imagined. Knowledge of this similarity can aid us in putting ourselves in the position of the other species that we so callously and selfishly use for our own purposes without consideration of their desires and interests, and without appreciation of their talents and capabilities. This ability to put ourselves in the position of another is an important aid in our moral life, and to ignore its use solely because we are considering the interests of animals would seem to be another instance of speciesism, a prejudice that humanity can and should transcend, just as racial prejudice should be overcome.

However, Steinbock has a point that our natural tendencies do not urge us to consistently put ourselves into the position of our fellow creatures, as we seem to have both an emotional resistance to doing so and a rather limited ability to do so, for as Thomas Nagel has so aptly articulated, we could not possibly imagine what it is like to be a bat (Nagel, 1974). Our second thought experiment resolves Steinbock's objection because it does not ask us to imagine having lesser intellectual or moral prowess. As such, we do not need to go with VanDeVeer's suggestion that we imagine ourselves as one of the other non-human sentient creatures on our planet. We can achieve the same result as VanDeVeer does by going an alternative route.

Let us now engage in our second thought experiment. Let us imagine that human beings are not at the top of earth's evolutionary chain in terms of intellectual ability and power, but rather are in the second highest position, somewhat similar to the present day chimpanzees and apes. This idea is in some respects not such a stretch. If evolution had proceeded more rapidly than it has, then we very well could have been in that position. In other words, another species could have broken off from the Homo sapiens evolutionary branch and developed greater intellectual abilities, a more advanced morality, and superior technological capabilities than our own-at the same time that humans continued to populate the earth. Alternatively, we could project our thinking many years into the future when there could be both human beings and a species more advanced than we are populating the earth at the same time. In either case, let us imagine that humans are not in control; rather, there is another species endemic to earth and exercising its power over us in a similar fashion to how we currently dominate all the other animals with which we share the planet.

Moreover, we will apply Rawls' veil of ignorance to the present thought experiment so that when coming up with the rules and principles of society we will not know if we are a human being or a member of the more advanced and powerful species endemic to earth. We need not imagine that we are one of the other animals on our planet. Let us suppose that there is an equal chance of our being either human or the more advanced earthly species. In such a case, knowing that we had a $50 \%$ chance of being a member of the weaker species, would we not demand a principle or rule of justice that states that one's species should not determine the rights and respect they receive? I think we would clearly demand such consideration because we would see that one's species and

\footnotetext{
${ }^{22}$ VanDeVeer explains his point as follows: "Indeed if the original position were designed differently and its participants were aware of a likelihood of being born of a certain race, and, thus, chose principles whose application would yield favored positions for members of that race, we should say that the very design of the position guaranteed the choice of racist principles. Unless the assumption of membership in Homo Sapiens can be shown to be non-arbitrary, the claim that the original position is designed in a way guaranteeing the choice of speciesist principles is not implausible.” (VanDeVeer, 1979: p. 374)
} 
its power should not be determinative of how an entity is treated.

Note that this other more advanced species might look at human beings as quite morally primitive and undeveloped —as we tend to look at the great apes. In spite of this, certainly we would think it wrong to be mistreated merely because we were of another species - a species which was not powerful enough to be in control of its own destiny. This should lead us to see that we are in some sense lucky to presently be the "top dog" in the evolutionary chain on earth. It could have been different.

We should also note that while Rawls' veil of ignorance seeks to help people and not animals, in at least one respect it is more ambitious than my own use of the proper role for luck to play in our morality. I am proposing that the idea of luck be utilized in order to prevent others (animals) from being harmed, while one of Rawls' primary uses of the concept of luck is to assist others. It is usually viewed as a more demanding moral burden to be required to help others, especially strangers, than it is to merely avoid harming others. ${ }^{23}$ I am asking humans to use the idea of luck to stop the mistreatment of animals that causes these animals significant and avoidable pain, suffering and death.

When we see someone who has a severe physical disability, most of us feel fortunate that we do not have to deal with the challenges that person likely must overcome. Similarly, it can be viewed as luck if we are born into a wealthy family instead of a poor one; if we have loving parents instead of abusive ones; if we are intellectually gifted instead of mentally disabled; and if we are born well-fed in the United States instead of starving in a country such as Bangladesh. We are empathetic because we realize it could have been otherwise.

I believe that this same attitude or belief is behind the reaction many of us have toward racism. We realize that we could have been born into the non-dominant race in a racist country. It is often not easy to be a part of a minority race, religion, or culture that is not in power.

It seems to me that this idea of luck could and should also be utilized as a motivation to be kinder and gentler to our fellow creatures-for in much the same way that we could have been born physically or mentally disabled, or in a poverty stricken part of the world, we could also have been born into a position of weakness or subservience, as the animals are in now, instead of the position of strength and domination that humans find themselves in today. ${ }^{24}$

As previously mentioned, Singer believes that our treatment of animals reveals a prejudice towards our own species and to the detriment of other species---what he calls "speciesism." Although Singer, as far as I know, never expressly mentions the idea of luck, it clearly is lurking in the background. We justify our poor treatment of other people and other creatures on selfish and insensitive grounds, and if we stopped to think about it, we could have been in the position of the recipient of the abuse perpetrated by another. Luck has allowed many of us to escape a myriad of abuses, but it has not done well for the animals that we so cruelly treat. When we engage in speciesism we ignore our luck of having been born as a human being — the most advanced and powerful beings on this planet at this time.

As previously mentioned, Rawls does not believe that his technique for finding the just rules for a society can be used to protect animals. However, it is clear that the idea of luck plays a prominent role in his thinking too. Rawls' two main principles for societal justice are based on the idea that society should help the people who are unfortunate or unlucky enough to be born with either social disadvantages, such as being born into a poor and powerless family, or physical disadvantages, such as being born mentally impaired or physically handicapped. Rawls believes that this idea has been fundamental to our modern Western democracies. Rawls explains his thinking as follows:

\footnotetext{
${ }^{23}$ For example, a requirement to help others that is carried out and enforced by the state, such as by taxing people and using those taxes to pay for a welfare system, would seem to be a much more stringent moral requirement than the more basic requirement to avoid killing and injuring others. Of course, according to Rawls, we have a duty to redress inequalities in natural and social starting places because behind the veil of ignorance we would have agreed to help those in such a position—-since those people could be us or our loved ones. Since he believes that helping others is part of the principles of distributive justice to which we would have agreed, it seems to follow that we would not and should not view helping others as a burden or as onerous or as an improper moral requirement. Those principles which impose obligations to help others are part of the just society we want. However, given this, it still remains true that a requirement to help others, even though we want such a requirement, is still usually considered a stronger, more demanding, or more burdensome moral requirement than laws which merely forbid one from harming others. Immanuel Kant recognized the distinction between helping others and not harming them in his differentiation between perfect and imperfect duties. Because the imperfect duties of helping others and developing our talents are more demanding than merely the duty not to unnecessarily harm others, Kant believed that we had wide latitude regarding when and how to fulfill our imperfect duties (See Kant, 1797: pp. 32-33).

${ }^{24}$ The idea of luck in the moral assessment of behavior has been raised in contexts very different than the present one. For example, Thomas Nagel uses the concept of "moral luck" when comparing the drunk driver who runs over a child to the same driver who is lucky that no child is around when he swerves onto the sidewalk. Likewise, we blame the coward who fails to save a child, and yet some cowards are lucky that they are never faced with situations where their cowardice would be displayed (Nagel, 1979: pp. 98-109).
} 
This is the principle that undeserved inequalities call for redress; and since inequalities of birth and natural endowment are undeserved, these inequalities are to be somehow compensated for...society must give more attention to those with fewer native assets and to those born into less favorable social positions (Rawls, 1971, 1999: p. 86).

Our position on this planet as the most powerful beings is clearly a stroke of good luck for us, and is undeserved in the Rawlsian sense. Using a Rawlsian-type analysis, we should be helping the animals, as they are less fortunate and less powerful, and certainly not harming them. Instead of redressing the inequalities, we have taken advantage of them for our own selfish benefit. ${ }^{25}$

Not only is our position of power undeserved, but so is our degree of intelligence and our ability to at times behave rationally. It is not through our own merit that we are intelligent and sometimes rational. I play no role in having the attributes of intelligence and rationality (although I do have a role in their development and growth). I owe my basic intelligence and rationality to nature and evolution, not my own efforts, and am fortunate to have these attributes to a greater degree than the other animals on our planet. Animals certainly have many abilities, talents, and skills which humans do not possess, but unfortunately for them they are not the kinds of abilities which would make them immune from human dominance. Humans cannot run as fast as a cheetah, jump as far or as high as a kangaroo or a snow leopard, fly like an eagle, live underwater like a fish, see as well as a hawk, nor hear what an elephant can hear. We are fortunate to have the evolutionary advantages of a highly developed brain, and it is primarily this one evolutionary advantage that has allowed us to dominate our planet and dictate the fate of the other living beings here.

Indeed, in some sense luck has played a role regarding whether we were born American, Syrian, or Ethiopian; Caucasian, Hispanic, Asian, or Black; physically disabled or healthy; and at the top rung of evolution or less intellectually advanced and powerful. As moral beings, we should not use our good luck of being born into the species that is at the top of the evolutionary chain as an excuse for preying on other beings when we need not do so.

\section{Conclusion: How to Use Our Greater Gifts}

The defenders of our current treatment of animals emphasize that humans are so much more advanced intellectually and morally than the animals that we eat and use for our own purposes. It is these superior abilities that are supposed to justify our callous treatment of animals. I think that the defenders of the status quo have it backwards. It is precisely because we are more advanced intellectually and morally that we can and should behave more respectfully and benevolently towards animals. The critics of animal rights are correct in focusing on our mental and moral superiority, but it is ironic indeed that our morality has provided the basis for our immoral treatment of those less articulate, intelligent and powerful. On the contrary, our greater moral capacities should inspire us to treat the animals in a way of which we can be proud, in a way where our morality shines through.

Accordingly, the differences between ourselves and animals are irrelevant insofar as those differences are being used to justify our insensitive treatment of animals. The two thought experiments are intended to show that we do not believe it would be proper for either aliens or a more advanced species on our own planet to mistreat and use us for their own purposes merely because they are intellectually superior to us and thereby able to dominate us. If such behavior would be wrong toward us, then our behavior toward the animals is equally wrong.

Indeed, we are causing great harm and death to our fellow creatures with whom we inhabit this planet, and we need not do so. For starters, we could and should stop eating meat, and we could and should limit the destruction of the many animal habitats that we are destroying. At a minimum, we should reduce our meat-eating habit and raise the animals we eat in a much more humane manner where their lives are not ones of constant suffering. Whenever possible, we should avoid using animals in our medical experiments by finding alternative ways to test our medicines and other products, and if we do use them, we should make every attempt to minimize their suffering. Additionally, we should be conscious that these animals are living, breathing, caring, and intelligent beings, and our zoos and circuses should reflect this knowledge.

\footnotetext{
${ }^{25}$ One might assert that being born an animal does not call for redress. In isolation, of course, that is correct. However, we are here focusing on the redress needed due to natural inequalities which places the animal at a disadvantage when compared to human abilities. For example, if the average human I.Q. were much lower that it is now, as it undoubtedly was in the past, then there would be no need of redress for someone of that I.Q. since that level of I.Q. would not place that person at a disadvantage when compared to the norm. They would be the norm. However, that same lower I.Q. may call for redress today if it places one at a disadvantage when compared to the higher average I.Q. present now.
} 
We are fortunate to be the most intellectually advanced and thereby powerful beings on the planet. Power when used wisely can achieve great things, but when used to oppress others is wrong. When those others cannot speak-at least not in a language that we can understand, the oppression can go virtually unnoticed. We are the only ones who can speak on behalf of the animals. We are the only ones who can object-and it is time that more of us did so, if for no other reason than we are the ones who are harming them.

\section{References}

Abbey, R. (2007) Rawlsian Resources for Animal Ethics. Ethics \& the Environment, 12, 1-22. http://dx.doi.org/10.2979/ETE.2007.12.1.1

American Farmland Trust. www.farmland.org/no-farms-no-food

Armstrong. S., \& Botzler, R. (2003, 2008) The Animal Ethics Reader ( $1^{\text {st }}$ and $2^{\text {nd }}$ ed.). London \& New York: Routledge.

Bedard, I. (2014) Orangutans Share Their Future Plans With Others. Scientific American, 25, Issue 3.

Bentham, J. (1789) Introduction to the Principles of Morals and Legislation. London: Athlone Press. http://dx.doi.org/10.1093/oseo/instance.00077240

Campbell, C., \& Campbell, T. (2006) The China Study. Dallas: Benbella Books.

Cigman, R. (1980) “Animals Do Not Have Rights” Excerpted from Death, Misfortune and Species Inequality. Princeton, NJ: Princeton University Press.

Davis, W. (1976) Man-Eating Aliens. The Journal of Value Inquiry, 10, 178-185. http://dx.doi.org/10.1007/BF00137312

De Waal, F. (1996) Good Natured. Cambridge, MA: Harvard University Press.

Dostoyevsky, F. (1864). Reprinted in Existentialism (2nd ed.). New York: Oxford University Press, 2005, 42, 46.

Friend, T. (2004) Animal Talk: Breaking the Codes of Animal Language. New York: Free Press, Simon \& Schuster, Inc.

Gill, V. (2014) River Turtle Mothers “Talk” to Their Hatchlings. B.B.C. News

Hasenjager, M., \& Dugatkin, L. (2015) The Networked Animal. Scientific American.

Hume, D. (1779). Dialogues Concerning Natural Religion, Part II. New York: Barnes \& Noble.

International Campaign to Abolish Nuclear Weapons. www.ican.org/the-facts/catastrophic-harm/

International Society of Krishna Consciousness (1983). The Higher Taste. Location: Bhaktivedanta Books.

Jones, R. (2013). Science, Sentience, and Animal Welfare. Biology \& Philosophy, 28, 1-30.

http://dx.doi.org/10.1007/s10539-012-9351-1

Kant, I. (1797). The Metaphysics of Morals. Cambridge: Cambridge University Press

Kennedy, J. S. (1992). The New Anthropomorphism. Cambridge: Cambridge University Press. http://dx.doi.org/10.1017/CBO9780511623455

LaFollette, H. (1989). Animal Rights \& Human Wrongs. In N. Dower (Ed.), Ethics and the Environment (pp. 79-90). Gower Press.

Montgomery, S. (2015). What the Octopus Knows. Los Angeles Times, 6 October, A13.

Moussaieff Masson, J., \& McCarthy, S. (1995). When Elephants Weep: The Emotional Lives of Animals. New York: Delta/ Dell Publishing.

Nagel, T. (1979). Mortal Questions. Cambridge: Cambridge University Press.

Nagel, T. (1974). What Is It Like to Be a Bat? Philosophical Review, 83, 435-450. http://dx.doi.org/10.2307/2183914

Nuclear Darkness (2016). www.nucleardarkness.org/nuclear/effectsofnuclearweapons

PETA (People for the Ethical Treatment of Animals) (2016). www.peta.org/issues/animals-used-for-experimentation/animals-used-experimentation-factsheets/product-testing-toxic-tra gic/

Pritchard, M., \& Robison, W. (1981). Justice and the Treatment of Animals: A Critique of Rawls. Environmental Ethics, 3, 55-61. http://dx.doi.org/10.5840/enviroethics19813133

Rachels, J. (1977). Vegetarianism and "the Other Weight Problem”. World Hunger and Moral Obligation i/e (P) Aiken/LaFollette. In J. White (ed.), Contemporary Moral Problems (7th ed., pp. 496-505). Wadsworth: Thomson Learning.

Rawls, J. (1971, 1999). A Theory of Justice (Revised ed.). Cambridge, MA: The Belknap Press of Harvard University Press.

Regan, T. (1983). The Case for Animal Rights. Berkeley, CA: University of California Press.

Rowlands, M. (1998). Animal Rights: A Philosophical Defense. New York: Palgrave. 
Singer, P. (1975). Animal Liberation. New York: Avon Books.

Singer, P. (1993). Practical Ethics (2nd ed.). Cambridge: Cambridge University Press.

Singer, P. (2009a). Reply to Bernard Williams. In J. Shaler (Ed.), Peter Singer under Fire (pp. 97-101). Peru, IL: Open Court Publishing Company.

Singer. P. (2009b). Speciesism and Moral Status. Metaphilosophy, 40, 567-581. http://dx.doi.org/10.1111/j.1467-9973.2009.01608.x

Slobodchikoff, C., Paseka, A., \& Verdolin, J. L. (2009). Prairie Dog Alarm Calls Encode Labels about Predator Colors. Animal Cognition, 12, 435-439. http://dx.doi.org/10.1007/s10071-008-0203-y

Slobodchikoff, C. (2012). Chasing Doctor Doolittle: Learning the Language of Animals. New York: St. Martin’s Press.

Steinbock, B. (1978). Speciesism and the Idea of Equality. Philosophy, 53, 247-256. http://dx.doi.org/10.1017/S0031819100016582

Talbert, M. (2006). Contractualism and Our Duties to Nonhuman Animals. Environmental Ethics, 28, 201-215. http://dx.doi.org/10.5840/enviroethics200628232

Thomas, A. (1996). Movie: To Love or Kill: Man v. Animal. Programming/America Undercover Series.

Tribe of the Heart, Ltd. (2004). Movie: Peaceable Kingdom. Ithaca, NY.

VanDeVeer, D. (1979). Of Beasts, Persons, and the Original Position. The Monist, 62, 368-377. http://dx.doi.org/10.5840/monist197962325

Vegan Outreach (2016). Why Vegan. www.veganoutreach.org

Williams, B. (2009). The Human Prejudice. In J. Shaler (Ed.), Peter Singer under Fire (pp. 77-96). Peru, IL: Open Court Publishing Company.

\section{Submit or recommend next manuscript to SCIRP and we will provide best service for you:}

Accepting pre-submission inquiries through Email, Facebook, LinkedIn, Twitter, etc. A wide selection of journals (inclusive of 9 subjects, more than 200 journals)

Providing 24-hour high-quality service

User-friendly online submission system

Fair and swift peer-review system

Efficient typesetting and proofreading procedure

Display of the result of downloads and visits, as well as the number of cited articles

Maximum dissemination of your research work

Submit your manuscript at: http://papersubmission.scirp.org/ 